Int. J. Electrochem. Sci., 11 (2016) 3206 - 3226

\title{
Effect of Solution Heat Treatment on Microstructure and Wear and Corrosion Behavior of a Two Phase $\beta$-Metastable Titanium Alloy
}

\author{
Khaled M. Ibrahim ${ }^{1,2}$, M. Mahmoud Moustafa ${ }^{1,3}$, Mubarak W. Al-Grafi ${ }^{1}$, Nader El-Bagoury ${ }^{2,4}$, \\ Mohammed A. Amin ${ }^{4,5}$, \\ ${ }^{1}$ Taibah University, College of Engineering, P.O. Box. 344 Al-Madinah Al-Mounwara, Saudi Arabia \\ ${ }^{2}$ CMRDI, P.O. Box 87 Helwan, Cairo, Egypt \\ ${ }^{3}$ Production Engineering and Design Department, Minia University, Faculty of Engineering, Minia, \\ Egypt \\ ${ }^{4}$ TAIF University, Chemistry Department, Faculty of Science, P.O. Box 888, El-Haweyah, Saudia \\ Arabia \\ ${ }^{5}$ Department of Chemistry, Faculty of Science, Ain Shams University, 11566 Abbassia, Cairo, Egypt \\ *E-mail: maaismail@yahoo.com
}

doi: $10.20964 / 110403206$

Received: 19 September 2015 / Accepted: 29 January 2016 / Published: 1 March 2016

\begin{abstract}
A low cost beta titanium (LCB Ti) alloy with a composition of Ti-6.62Mo-4.53Fe-1.45Al-0.14O was subjected to solution heat treatment process at two different temperatures, namely $650{ }^{\circ} \mathrm{C}$ and $750{ }^{\circ} \mathrm{C}$. Each heat treated process was followed by ageing at $500{ }^{\circ} \mathrm{C}$ for $4 \mathrm{hrs}$. The obtained microstructures were studied and their influence on the mechanical and chemical properties of the LCB Ti-alloy was reported. The $\mathrm{Ti}$ alloy that is heat treated at $650{ }^{\circ} \mathrm{C}$ (designated here as alloy I), showed a fine microstructure with $15 \%$ volume fraction of fine continuous $\alpha$-phase at the $\beta$-grains. The microstructure of the $\mathrm{Ti}$ alloy when heat treated at $750{ }^{\circ} \mathrm{C}$ (alloy II) was coarse with $10 \%$ of discontinuous $\alpha$-phase formed at the $\beta$-grains. A high tensile strength of $1492 \mathrm{MPa}$ was obtained for alloy I due to its fineness microstructure. However, alloy II recorded a low strength of $1295 \mathrm{MPa}$ due to its coarse $\alpha-\beta$ microstructure. The uniform corrosion characteristics of alloys I and II was studied in $3.5 \% \mathrm{NaCl}$ solutions employing Tafel polarization, linear polarization resistance (LPR), and electrochemical impedance spectroscopy (EIS) techniques. The anodic behavior of these materials was also assessed adopting potentiodynamic anodic polarization and chronoamperometry measurements. The corrosion behavior of a spring steel alloy was also included for comparison. Alloy II recorded the highest (superior) corrosion resistance among the tested alloys. Microstructure features and spontaneous passivation of alloys I and II were used to account for their high corrosion resistance, as compared with spring steel.
\end{abstract}


Keywords: Corrosion, Wear, LCB Titanium alloys, Solution treatment, $\alpha$-phase.

\section{FULL TEXT}

(C) 2016 The Authors. Published by ESG (www.electrochemsci.org). This article is an open access article distributed under the terms and conditions of the Creative Commons Attribution license (http://creativecommons.org/licenses/by/4.0/). 